East European Journal of Physics

East Eur. J. Phys. 2. 127-134 (2021)

DOI: $10.26565 / 2312-4334-2021-2-10$

PACS: $71.20 . \mathrm{Rv}, 73.20 .-\mathrm{r}, 72.80 .-\mathrm{r}$

\title{
INVESTIGATION ON ELECTRICAL PROPERTIES OF SOLID POLYMER SHEETS (HDPE AND LDPE) AT AUDIO FREQUENCY RANGE
}

\author{
(D)Sarat K. Dasha,*, (D)Hari S. Mohanty ${ }^{\mathrm{b}}$, Diswajit Dalai ${ }^{\mathrm{b}, \dagger}$ \\ ${ }^{a}$ Department of Physics, Regional Institute of Education (NCERT), Bhubaneswar, Odisha, 751022, India \\ ${ }^{b}$ Department of Physics, School of Sciences, GIET University, Gunupur 765022, Odisha, India \\ *Corresponding author: skdash59@yahoo.com, ‘biswajit@giet.edu \\ Received February 15, 2021; revised March 31, 2021; accepted April 12, 2021
}

Two different groups of solid polymer sheets: low density polyethylene (LDPE) sample of thickness $0.006 \mathrm{~cm}$ and $0.007 \mathrm{~cm}$ along with high density polyethylene (HDPE) sample of the thickness of $0.009 \mathrm{~cm}, 0.010 \mathrm{~cm}$ were taken in this work. The measurement of electrical properties such as dielectric constant, $\varepsilon^{\prime}$ and dielectric loss, $\varepsilon^{\prime \prime}$ for LDPE and HDPE polymer sheets have been measured using a dielectric cell. The dielectric cell has been fabricated which consists of two circular parallel plates of pure stainless steel each of $5 \mathrm{~cm}$ diameter and $2 \mathrm{~mm}$ thickness. An impedance bridge (GRA 650A) was used for measurement of capacitance, $C$, and dissipation factor, $D$ in the audio frequency (AF) range, $100 \mathrm{~Hz}$ to $10 \mathrm{kHz}$. Different samples were loaded in between the two plates of the cell and the capacitance as well as the dissipation factor were estimated from the dial readings of the bridge. Effect of frequency variation on $\varepsilon^{\prime}$, $\varepsilon^{\prime \prime}$, relaxation time, $\tau$, dissipation factor, $\tan \delta$ and ac conductivity, $\sigma$ were also discussed at audio frequency range. The complex permittivity, $\varepsilon^{*}$, related to free dipole oscillating in an alternating field and loss tangent, $\tan \delta$ were calculated. The frequency-dependent conductivity, dielectric behavior, and electrical modulus, both real $\left(M^{\prime}\right)$ and imaginary $\left(M^{\prime \prime}\right)$ parts of LDPE and HDPE have been studied in this work. The values of the real part of the electrical modulus $\left(M^{\prime}\right)$ did not equal to zero at low frequencies and it is expected that the electrode polarization may develop in both sheets. These findings reveal an increased coupling among the local dipolar motions in a short-range order localized motion. The analysis of real $\left(\varepsilon^{\prime}\right)$ and imaginary $\left(\varepsilon^{\prime \prime}\right)$ parts of dielectric permittivity and that electrical modulus real $\left(M^{\prime}\right)$ and imaginary $\left(M^{\prime \prime}\right)$ parts signify poly dispersive nature of relaxation time as observed in Cole-Cole plots.

KEY WORDS: LDPE, HDPE, dielectric constant, dielectric loss, AC conductivity

In continuation of our earlier analysis on characterization and dielectric properties of barium zirconium titanate prepared by solid state reaction and high energy ball milling processes [1], the electrical properties of solid polymer sheet have been studied in this work which enable the industry to elicit the characteristic information as regards to its use as insulator having high dielectric breakdown strength, low dielectric loss and the ability to be easily processed and also recycled when cross linked [2,3]. The measurement of dielectric constant is recognized as one of the important tool for understanding the molecular behavior of associating molecules [4]. Gradual evolution of dielectric theories based on such measurements has helped in this study further. The physico-chemical behavior of macromolecules could be ascertained from the study of the frequency and temperature variation of relative permittivity $\varepsilon^{\prime}$ and dielectric loss $\varepsilon^{\prime \prime}[5,6]$. Surface composition of the polymers primarily influences many industrial applications such as wetting, weathering, permeation friction, electrostatic charging and dye adsorption [7]. However, lack of precise information regarding functional groups and the surface region-a problem having no counterpart in polymer science, is an important impediment in this sphere. High density polyethylene (HDPE) and low density polyethylene (LDPE) are low cost, high tensile strength and percent elongation, has penetrated into the markets like stretching film, merchandizing bags and also non-packing application like industrial sheeting and agricultural film [8,9]. Attempt are being made to determine the size of surface micro-cracks of irradiated polythene terthaphalate (PET) with X-Rays and nonmonotonus dependence of dissociation rate of polymer on alkali solution [10]. The physico-chemical properties of LDPE with wood fiber, induced by ion-bombardment are being extensively studied [11, 12]. The physical and chemical nature of the macromolecules and the molecular mobility of the sub-molecules can be deduced from the study of the variation of dielectric constant as well as dielectric loss with temperature and frequency and the position of the loss peak [13].

The dielectric properties of solid polyethylene have been investigated in audio frequency (AF) range because of large size of the molecules. In the present report, an attempt has been made to determine the values of dielectric constant $\left(\varepsilon^{\prime}\right)$ and dielectric loss $\left(\varepsilon^{\prime \prime}\right)$ of the solid polymers such as high density polyethylene (HDPE) and low density polyethylene (LDPE) by using an impedance bridge over a frequency range of $100 \mathrm{~Hz}$ to $10 \mathrm{kHz}$ at $303.16 \mathrm{~K}$. The cost of the design is relatively less compared to any other versatile system and can be inducted as standard experiment at an appropriate level.

\section{THEORY}

The most generally used methods for measuring dielectric constant $\left(\varepsilon^{\prime}\right)$ and loss $\left(\varepsilon^{\prime \prime}\right)$ consists of the measurement of the capacitance of an empty capacitor and the capacitance of the capacitor filled with the dielectric material. The capacitance $C$ of a capacitor is defined as the ratio of the charge on its plates to the potential difference between them. For a parallel plate capacitor, the capacitance $C$ can be calculated from the geometry of the system [14] (c) S. K. Dash, H. S. Mohanty, B. Dalai, 2021 


$$
C=\varepsilon_{0} \varepsilon^{\prime} \frac{A}{d},
$$

where $\varepsilon^{\prime}$ is the dielectric constant of the material a dimensionless property of the material between the two plates and $\varepsilon_{0}$ is the permittivity of free space. Here $A$ is the area of one of the plates and $d$ is the thickness of the material. The dielectric constant is thus conveniently expressed as the ratio of the capacitance of the capacitor with the material in place to its capacitance with vacuum (or air, for which $\varepsilon^{\prime}=1.0005$ at $20^{\circ} \mathrm{C}$ ) between the plates. If a loss-free dielectric is considered in an alternating electric field, there would be no dissipation of energy, and charging voltage and current in a capacitor would be $90^{\circ}$ out of phase. But when subjected to an alternating field, the polar molecules of a system rotate towards an equilibrium distribution in molecular orientation with corresponding dielectric polarization. Due to either very large size of the polar molecule or high frequency of the alternating field, the rotating motion of the molecule may not be sufficiently rapid for attaining equilibrium, and then the polarization acquires a component out of phase with the electric field $[15,16]$. The current through a capacitor, therefore, does not lead the voltage by $90^{\circ}$ but only by $\left(90^{\circ}-\delta\right)$ where $\delta$ is often called the loss angle. Therefore, the complex permittivity $\left(\varepsilon^{*}\right)$ related to free dipole oscillating in an alternating field is given by $[17,18]$,

$$
\varepsilon^{*}=\varepsilon^{\prime}-j \varepsilon^{\prime \prime}=\varepsilon_{\infty}+\frac{\varepsilon_{S}-\varepsilon_{\infty}}{1+j \omega \tau},
$$

where, $\varepsilon_{S}$ and $\varepsilon_{\infty}$ are the low and high frequency value of $\varepsilon^{\prime}(\omega), \omega=2 \pi f$, here $f$ being the measuring frequency and $\tau$ is the relaxation time.

The real part of $\varepsilon^{*}[19]$ is

$$
\varepsilon^{\prime}=\varepsilon_{\infty}+\left(\varepsilon_{S}-\varepsilon_{\infty}\right) \frac{\omega \tau}{1+\omega^{2} \tau^{2}}
$$

The real part $\varepsilon^{\prime}$ is calculated as [20],

$$
\varepsilon^{\prime}=\frac{C}{C_{a}}\left(\frac{1}{1+\tan ^{2} \delta}\right),
$$

where $C$ is the measured capacitance, $C_{a}$ is the empty capacitance and $\tan \delta$ is the loss tangent.

The imaginary part of $\varepsilon^{*}$ is given by [20]

$$
\varepsilon^{\prime \prime}=\left(\varepsilon_{S}-\varepsilon_{\infty}\right) \frac{\omega \tau}{1+\omega^{2} \tau^{2}}
$$

The imaginary part $\varepsilon^{\prime \prime}$ is the loss factor and calculated as

$$
\varepsilon^{\prime \prime}=\varepsilon^{\prime} \tan \delta
$$

The loss tangent is given by $[21,22]$

$$
\tan \delta=\frac{\varepsilon^{\prime \prime}}{\varepsilon^{\prime}}
$$

The capacitance of a capacitor is

$$
C=\varepsilon^{\prime} C_{a},
$$

where $C_{a}$ is the empty capacitance and $\varepsilon^{\prime}$ is the relative permittivity of the medium between the plates. The problem reduces to the measurement of capacitance of a capacitor with and without the dielectric medium for which $\varepsilon^{\prime}$ is calculated. The dielectric loss factor, $\varepsilon^{\prime \prime}$ is measured by an electrical bridge using the equation

$$
\varepsilon^{\prime \prime}=\varepsilon^{\prime} D v,
$$

where $D$ is the dissipation factor and $v$ is the operating frequency.

With measured values of $\varepsilon^{\prime}$ and $\varepsilon^{\prime \prime}$ at a number of frequencies above the glass transition temperature, the ColeCole plot $\left(\varepsilon^{\prime} \sim \varepsilon^{\prime \prime}\right)$ can also be drawn.

\section{TEST METHODS}

Description of the dielectric cell

The fabricated dielectric cell (Fig.1) consists of two circular parallel plates of pure stainless steel each of $5 \mathrm{~cm}$ diameter and $2 \mathrm{~mm}$ thickness. The entire system was enclosed in a wooden box of dimension $15 \mathrm{~cm} \times 15 \mathrm{~cm} \times 20 \mathrm{~cm}$ with removable glass plate in the front panel for loading the sample. The dielectric cell was used to measure the dielectric constant of the specimens. 


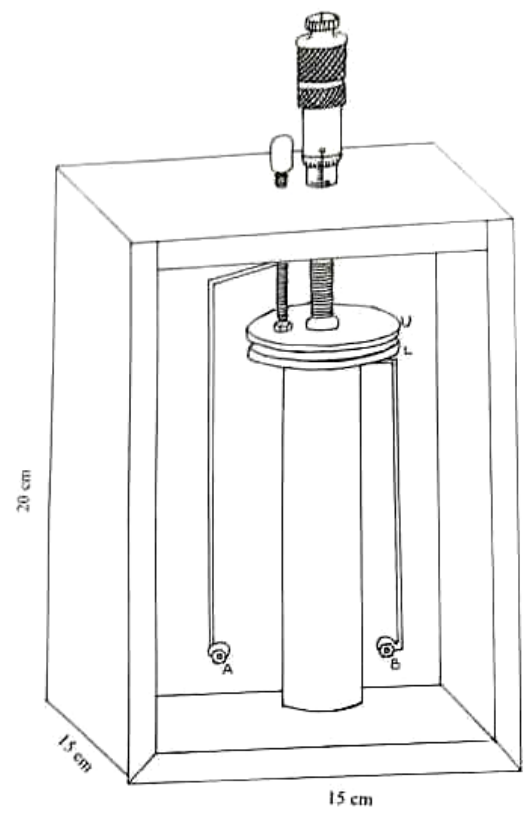

Figure 1. Dielectric cell set up

relation:
The lower plate was mounted horizontally using insulating adhesive on a plane glass plate fixed over a wooden upright. It was used as a static plate of the capacitor. The upper plate was rigidly fitted at its center to the movable head of a micrometer screw for its vertical movement while maintaining both the plates parallel to each other. The mounting of both the plates was perfectly horizontal so that both plates, when in contact, touch each other over the entire surface. The initial reading of the micrometer screw head was taken under this condition. The specimen in the form of thin plane sheets was cut into circular shape with diameter equal to that of the plates. To insert the sample between the two plates, the upper plate was moved up and the sample was placed between the plates. Therefore, the screw head was moved down till the sample sandwiched between the two plates and the final reading of the micrometer screw head was taken. These readings were used to compute the thickness of the sample. Two terminals, electrically connected to the two plates of the capacitor, were provided on the body of the box for connecting the capacitor to the bridge. The static lower plate was connected directly while the movable upper plate connected through a metal spring. The stud of the micrometer screw was held in position by fixing to the upper casing of the box.

\section{Stray capacitance}

The capacitance, $C$, of the capacitor used in this case is given by the

$$
C=\frac{\varepsilon_{0} \varepsilon^{\prime}}{4 \pi} \frac{A}{d}+C_{0}
$$

where $\varepsilon^{\prime}$ is dielectric constant of the sample, $A$ is area of cross section of each of the plates which is equal to the area of cross section of the sample, $d$ is distance between the plates which equals the thickness of the sample and $C_{0}$ is stray capacitance of the instrument.

The stray capacitance, $C_{0}$, of the instrument has been subtracted from the observed capacitance to get the corrected value to be used for measurement of $\varepsilon^{\prime}$. The following procedure was adopted for determining the stray capacitance of the instrument. The distance between the two plates was varied and the capacitance for different capacitors with air (as dielectric material) was measured (Table 1).

Table 1. Capacitance values of the cell with various thickness of air gap to determine the stray capacitance.

\begin{tabular}{|c|c|c|c|c|c|c|c|c|c|c|c|}
\hline $\begin{array}{c}\text { Thickness of the } \\
\text { air gap }(d) \text { in cm }\end{array}$ & 0.010 & 0.020 & 0.025 & 0.030 & 0.040 & 0.050 & 0.060 & 0.070 & 0.080 & 0.090 & 0.100 \\
\hline $\begin{array}{c}1 / \mathrm{d} \text { in } \\
\mathrm{cm}^{-1}\end{array}$ & 100 & 50 & 40 & 33.33 & 25 & 20 & 16.67 & 14.3 & 12.5 & 11.11 & 10.0 \\
\hline $\begin{array}{c}\text { Capacitance of the } \\
\text { cell in } \mathrm{C} \times 100 \mathrm{pF}\end{array}$ & 2.01 & 1.18 & 0.98 & 0.82 & 0.67 & 0.58 & 0.52 & 0.48 & 0.45 & 0.43 & 0.41 \\
\hline
\end{tabular}

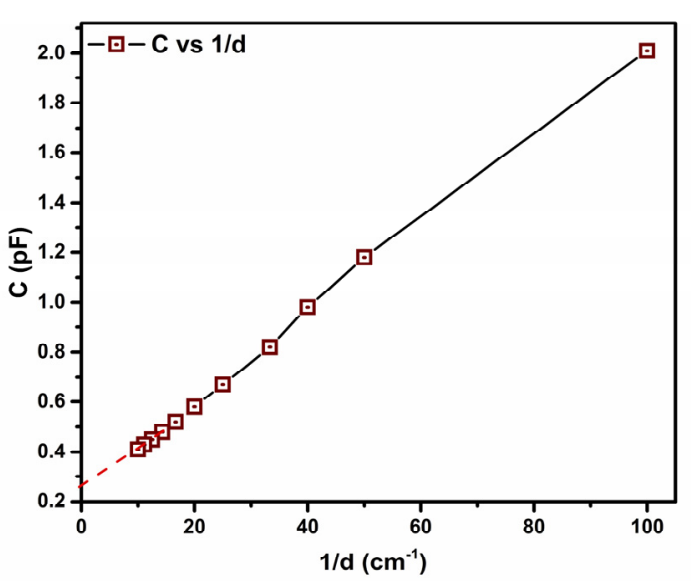

Figure 2. Determination of stray capacitance
A graph was plotted for $C$ vs. 1/d (Fig. 2). The nature of the graph shows a straight line with an intercept on the $\mathrm{Y}$-axis, which gives the value of stray capacitance, $C_{o}$, of the instrument, which includes the capacitance due to the connecting leads also.

\section{Impedance bridge}

The GRA impedance bridge model 650 A has been used for measurement of capacitance and dissipation factor. The bridge has an internal voltage source at $1 \mathrm{kHz}$. Alternatively, voltage source at different frequencies has also been applied externally. Different samples were loaded in between the two plates of the cell and the capacitance $C$ as well as the dissipation factor $D(=\tan \delta)$ were estimated from the dial readings of the bridge. The frequency of the voltage source was varied from $100 \mathrm{~Hz}$ to $10 \mathrm{kHz}$ and the above observations were repeated at number of frequencies in this range. Since the capacitance for air dielectric 
already recorded for different plate separations, its value $C_{a}$ was noted. This value is independent of frequency. The dielectric constant for each frequency is calculated from the relation:

$$
\varepsilon^{\prime}=\frac{C-C_{0}}{C_{a}-C_{0}}
$$

where $\varepsilon^{\prime}$ is dielectric constant of the material, $C_{0}$ is stray capacitance, $C_{a}$ is capacitance with air dielectric and $C$ is capacitance of the sample as dielectric.

Since the accuracy of measurement of $\varepsilon^{\prime}$ and $\varepsilon^{\prime \prime}$ depends on measurement of $C$ and $\tan \delta$ it is governed by the limit of accuracy of the impedance bridge used for measurement of $C$ and loss tangent. The accuracy of capacitance measurement over the range $1 \mathrm{pF}$ to $100 \mu \mathrm{F}$ was $1 \%$ while that of the dissipation factor measured over range of 0.002 to 1 was $5 \%$.

\section{Sample preparation}

Commercially available low density polyethylene (LDPE) sample of thickness $0.006 \mathrm{~cm}, 0.007 \mathrm{~cm}$ high density polyethylene (HDPE) sample of thickness of $0.009 \mathrm{~cm}, 0.010 \mathrm{~cm}$ were obtained from the Central Institute of Plastic Engineering and Technology (CIPET) Extension Centre, Bhubaneswar, India. The specimens were cut to the same size as that of the capacitor plates and put inside the cell for measurement of the experimental parameters $\varepsilon^{\prime}$ and $\varepsilon^{\prime \prime}$ of LDPE and HDPE. The measured value of $\varepsilon^{\prime}$ of HDPE agrees with the value of static dielectric constant $\varepsilon^{\prime}=3.2$ supplied by CIPET, Bhubaneswar.

\section{EXPERIMENTAL RESULTS AND THEIR DISCUSSION}

The frequency dependent conductivity, dielectric behavior and electrical modulus of LDPE and HDPE have been studied. The dielectric constant $\left(\varepsilon^{\prime}\right)$ and the dielectric loss factor $\left(\varepsilon^{\prime \prime}\right)$ of LDPE and HDPE samples were measured at temperature 303.16K. The relevant data are displayed graphically in Figs. 3-7 and presented in Table 2. The frequency dependence of $\varepsilon^{\prime}, \varepsilon^{\prime \prime}$ and $\tan \delta$ of LDPE and HDPE samples are shown in Fig. 3 and 4.
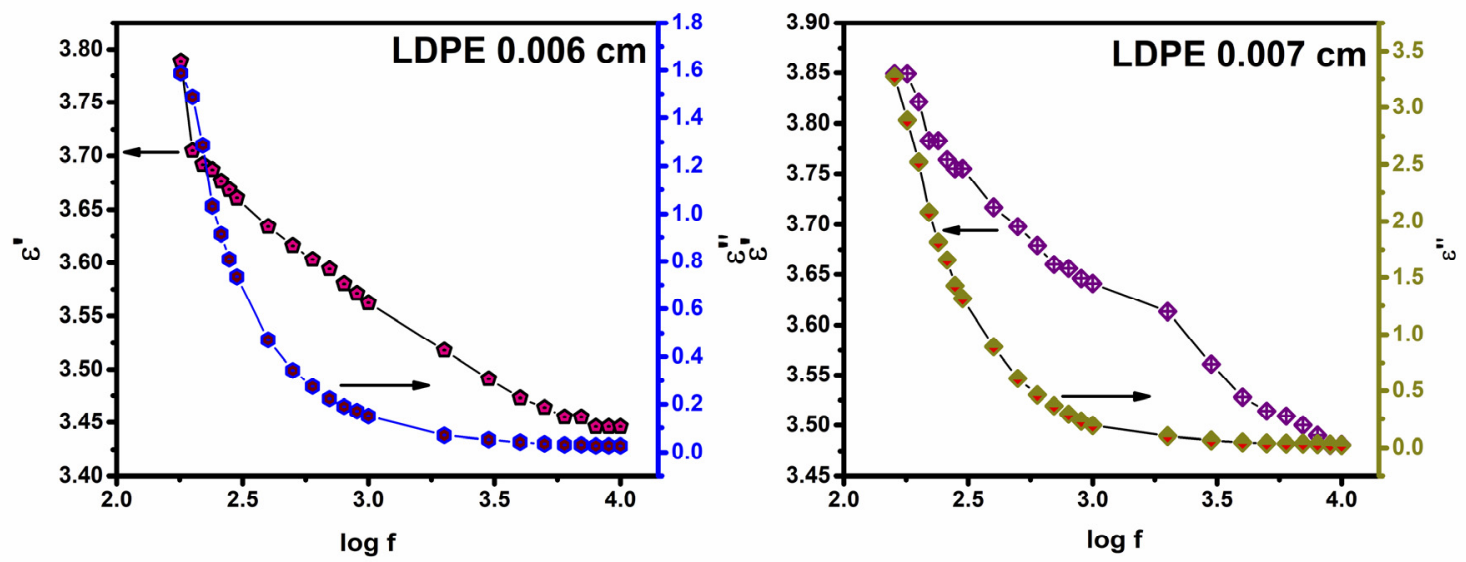

Figure 3. Variation of $\varepsilon^{\prime}$ and $\varepsilon^{\prime \prime}$ with frequency for LDPE sample having thickness $0.006 \mathrm{~cm}$ and $0.007 \mathrm{~cm}$.

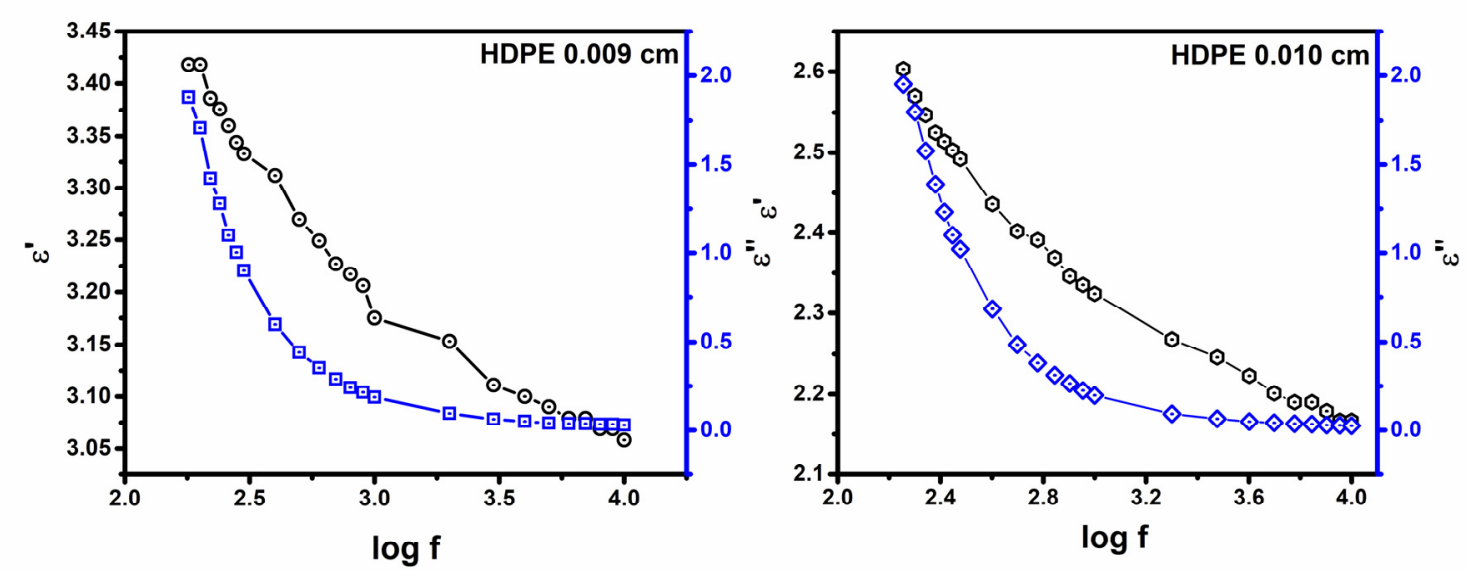

Figure 4. Variation of $\varepsilon^{\prime}$ and $\varepsilon^{\prime \prime}$ with frequency for HDPE sample having thickness $0.009 \mathrm{~cm}$ and $0.010 \mathrm{~cm}$. 
At very low frequencies, dipoles follow the field and the value of $\varepsilon^{\prime} \sim \varepsilon_{S}$ at quasi-static fields. The values of $\varepsilon^{\prime}$ slightly decrease with increase in frequency as the dipoles begin to lag behind the field. Dipole then no longer follow the field at high frequencies and $\varepsilon^{\prime} \sim \varepsilon_{\infty}$. Qualitatively such behavior is observed in the trend of $\varepsilon^{\prime}$ with frequency and in agreement with Eq. 3. Again, it is observed that there is substantial increase in dielectric constant $\varepsilon^{\prime}$ even at lower frequencies, attributes to a dipolar contribution of $\varepsilon^{\prime}(\omega)$ from hopping of electrons between isolated polaron and bipolaron state. The higher values of $\varepsilon^{\prime \prime}(\omega)$ at low frequency region may be due to the frequent charged motion within the sample $[19,20]$ which favors electrical conductivity effects. Using the relation, $\omega_{m}=1 / \tau$, the relaxation time, $\tau$ for the samples is found to be $8.846 \times 10^{-1} \mathrm{~s}$.
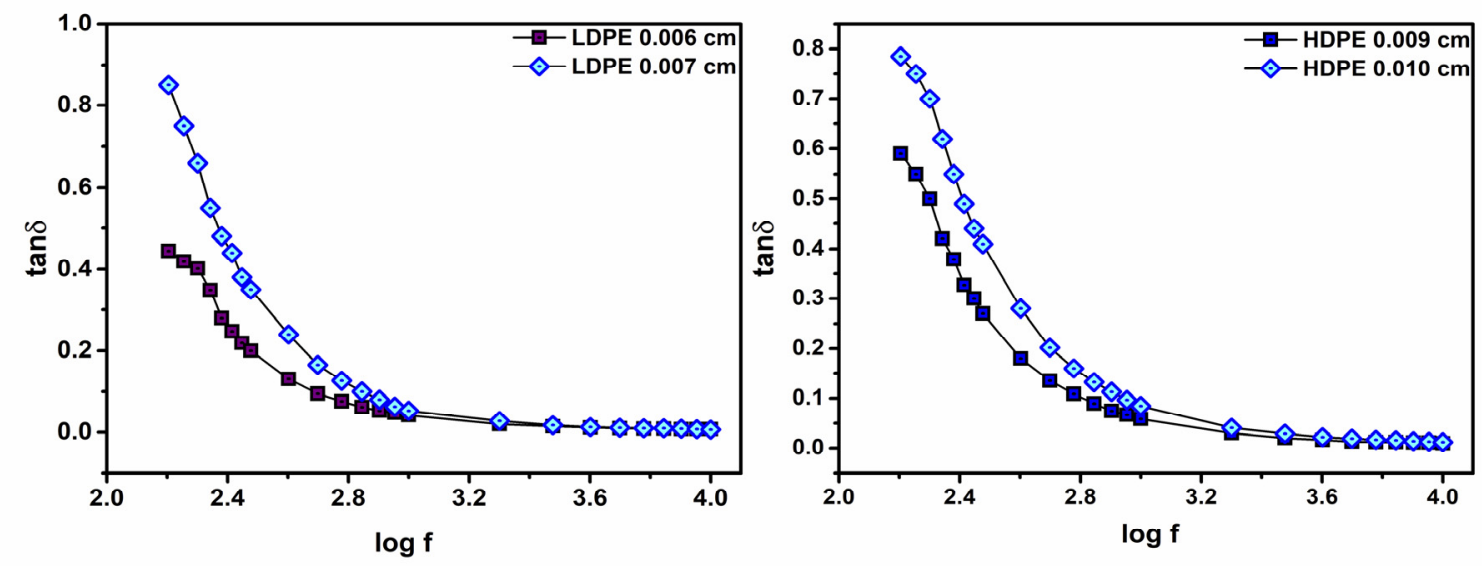

Figure 5. Variation of loss tangent with frequency for LDPE (thickness $0.006 \mathrm{~cm}$ and $0.007 \mathrm{~cm}$ ) and HDPE (thickness $0.009 \mathrm{~cm}$ and $0.010 \mathrm{~cm}$ ) samples.

Table 2. Dielectric constant, $\varepsilon^{\prime}$, dielectric loss, $\varepsilon^{\prime \prime}$ and dissipation factor, $\tan \delta$ of low density poly ethylene (LDPE) and high density poly ethylene (HDPE) samples.

\begin{tabular}{|c|c|c|c|c|c|c|c|c|c|c|c|c|c|}
\hline \multirow{2}{*}{$\begin{array}{c}\text { Frequency } \\
f \\
H z\end{array}$} & \multirow[b]{2}{*}{$\log f$} & \multicolumn{3}{|c|}{ LDPE $=0.006 \mathrm{~cm}$} & \multicolumn{3}{|c|}{ LDPE $=0.007 \mathrm{~cm}$} & \multicolumn{3}{|c|}{$\mathrm{HDPE}=0.009 \mathrm{~cm}$} & \multicolumn{3}{|c|}{$\mathrm{HDPE}=0.010 \mathrm{~cm}$} \\
\hline & & $\varepsilon^{\prime}$ & $\varepsilon^{\prime \prime}$ & $\tan \delta$ & $\varepsilon^{\prime}$ & $\varepsilon^{\prime \prime}$ & $\tan \delta$ & $\varepsilon^{\prime}$ & $\varepsilon^{\prime \prime}$ & $\tan \delta$ & $\varepsilon^{\prime}$ & $\varepsilon^{\prime \prime}$ & $\tan \delta$ \\
\hline 180 & 2.255 & 3.789 & 1.587 & 0.419 & 3.849 & 2.887 & 0.750 & 3.418 & 1.880 & 0.550 & 2.603 & 1.952 & 75 \\
\hline 200 & 301 & 3.705 & 1.488 & 0.402 & 821 & 2.522 & 0.660 & 3.418 & 1.709 & 0.500 & 2.570 & 1.799 & 0.700 \\
\hline 220 & 342 & 3.692 & 1.287 & 0.349 & .783 & 2.081 & 0.550 & 3.386 & 1.422 & 0.420 & 2.547 & 1.579 & 0.620 \\
\hline 240 & 380 & 3.687 & 1.032 & 0.280 & 3.783 & 1.816 & 0.480 & 3.376 & 1.279 & 0.379 & 2.525 & 1.389 & 0.550 \\
\hline 260 & 415 & 3.687 & 0.914 & 0.248 & 3.764 & 1.656 & 0.440 & 3.360 & 1.099 & 0.327 & 2.514 & 1.232 & 0.490 \\
\hline 280 & 447 & 3.687 & 809 & 0.219 & 3.755 & 1.427 & 0.380 & 3.344 & 1.003 & 0.300 & 2.503 & 1.101 & 0.440 \\
\hline 300 & 477 & 3.670 & 0.734 & 0.200 & 3.755 & 1.314 & 0.350 & 3.333 & 0.900 & 0.270 & 2.492 & 1.021 & .410 \\
\hline 400 & 602 & 3.634 & 0.472 & 0.130 & 3.717 & 0.892 & 0.240 & 3.312 & 0.596 & 0.180 & 2.436 & 0.682 & 0.280 \\
\hline 500 & 2.699 & 3.616 & 0.343 & 0.095 & 3.698 & 0.610 & 0.165 & 3.270 & 0.441 & 0.135 & 2.402 & 0.485 & 0.202 \\
\hline 600 & 778 & 3.603 & 0.274 & 0.076 & 3.679 & 0.463 & 0.126 & 3.249 & 0.354 & 0.109 & 2.391 & 0.382 & 0.160 \\
\hline 700 & 845 & 3.594 & 0.223 & 0.062 & 3.660 & 0.366 & 0.100 & 3.227 & 0.290 & 0.090 & 2.369 & 0.313 & 0.132 \\
\hline 800 & & 3.580 & 190 & 0.0 & 3.656 & 0.292 & 0.0 & 3.217 & 0.241 & 075 & 2.346 & 0.265 & 113 \\
\hline 900 & 954 & 3.571 & 171 & 0.048 & 3.646 & .230 & 0.0 & 3.206 & 0.215 & .067 & 2.335 & 0.226 & 0.097 \\
\hline 1000 & 000 & 3.562 & 0.150 & 0.042 & 3.641 & 0.193 & 0.053 & 3.175 & 0.187 & 0.059 & 2.324 & 0.197 & 0.085 \\
\hline 2000 & 3.301 & 3.518 & 0.070 & 0.020 & 3.613 & 0.101 & 0.028 & 3.153 & 0.095 & 0.030 & 2.268 & 0.093 & 0.041 \\
\hline 3000 & 477 & 3.491 & 0.052 & 0.015 & 3.561 & 0.064 & 0.018 & 3.111 & 0.062 & 0.020 & 2.246 & 0.065 & 0.029 \\
\hline 4000 & 3.602 & 3.473 & 0.042 & 0.012 & 3.528 & 0.046 & 0.013 & 3.100 & 0.050 & 0.016 & 2.223 & 0.049 & 0.022 \\
\hline 5000 & 3.699 & 3.464 & 0.035 & 0.010 & 3.514 & 0.039 & 0.011 & 3.090 & 0.040 & 0.013 & 2.201 & 0.042 & 0.019 \\
\hline 6000 & & 3.455 & 0.031 & 0.009 & 3.509 & 0.035 & 0.010 & 3.079 & 0.037 & 12 & 2.190 & 0.037 & 0.017 \\
\hline 7000 & & 3.455 & 0.031 & 0.009 & 3.500 & 0.035 & 0.010 & 3.079 & 0.037 & 0.012 & 2.190 & 0.035 & 0.016 \\
\hline 8000 & 903 & 3.446 & 0.027 & 0.008 & 3.490 & 0.031 & 0.009 & 3.069 & 0.034 & 0.011 & 2.179 & 0.030 & 0.014 \\
\hline 9000 & 3.954 & 3.446 & 0.027 & 0.008 & 3.481 & 0.028 & 0.008 & 3.069 & 0.034 & 0.011 & 2.167 & 0.028 & 0.013 \\
\hline 10000 & 4.000 & 3.446 & 0.027 & 0.008 & 3.481 & 0.024 & 0.007 & 3.058 & 0.030 & 0.010 & 2.167 & 0.026 & 0.012 \\
\hline
\end{tabular}

The results depict the high values of $\varepsilon^{\prime}$ and $\varepsilon^{\prime \prime}$ (Fig. 3-4) and $\tan \delta$ (Fig. 5) at frequencies lower than $1 \mathrm{kHz}$ increase with decreasing frequency, which may be due to space-charge polarization effect $[23,24]$ in building up of free charge at the interface between the sample and electrode. The gradual decrease of $\varepsilon^{\prime}, \varepsilon^{\prime \prime}$ and $\tan \delta$ with frequencies, 
may be due to typical characteristics of disordered polymer [24] which is in consistent with the findings of Himanshu et al. [25].
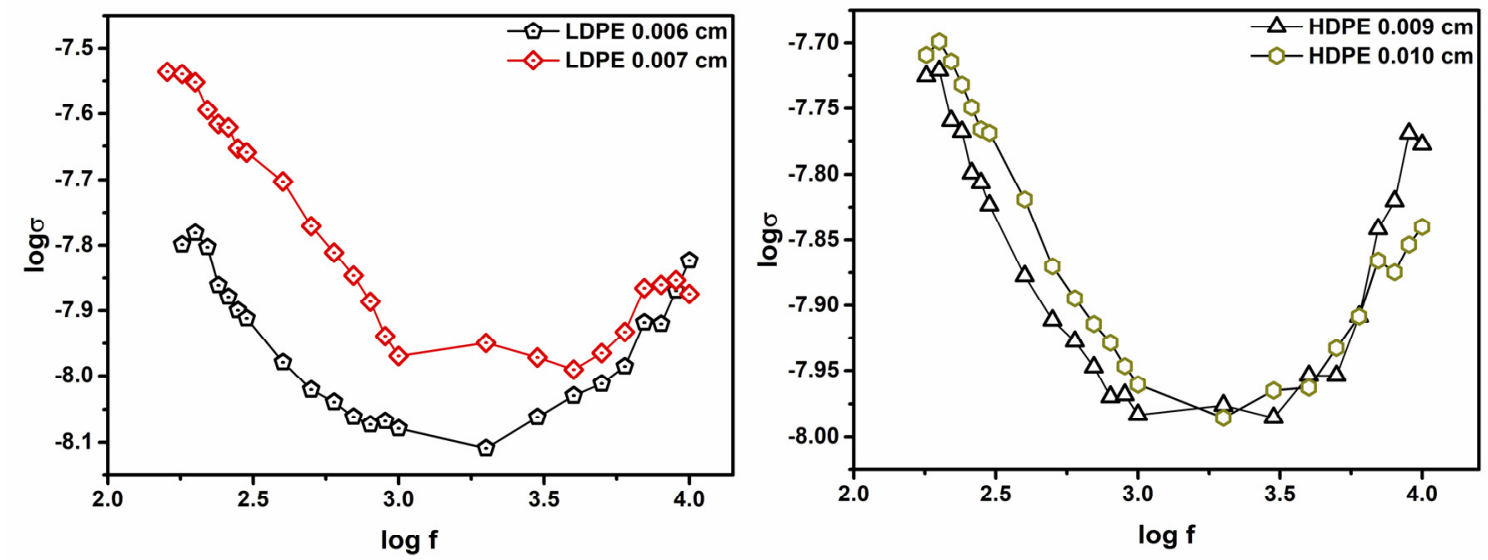

Figure 6. Variation of ac conductivity with frequency for LDPE (thickness $0.006 \mathrm{~cm}$ and $0.007 \mathrm{~cm}$ ) and HDPE (thickness $0.009 \mathrm{~cm}$ and $0.010 \mathrm{~cm}$ ) samples.

The frequency variation of ac conductivity is, $\sigma_{a c}=\varepsilon_{0} \omega \varepsilon^{\prime \prime}$ [26], where $\omega=2 \pi f$. The value of $\sigma_{a c}$ in Fig. 6 decreases non-linearly with frequency attending minima at about $6 \mathrm{kHz}$ then increases at higher frequency. The drops in $\sigma_{a c}$ indicate space charge polarization and electrode polarization $[18,19]$. The results of $\sigma_{a c}, \varepsilon^{\prime}(\omega)$ for LDPE and HDPE samples show that the charge transport does not occur via the usual mechanisms attributing in favour of insulating materials and the possibility of new mechanisms along fixed polaron sites.

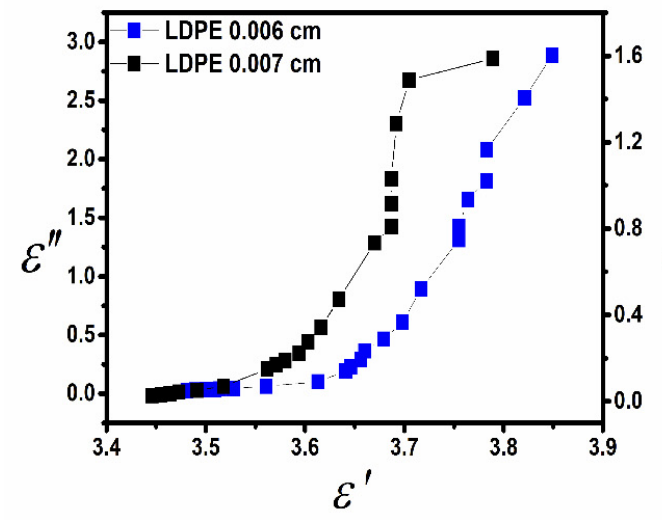

(a)

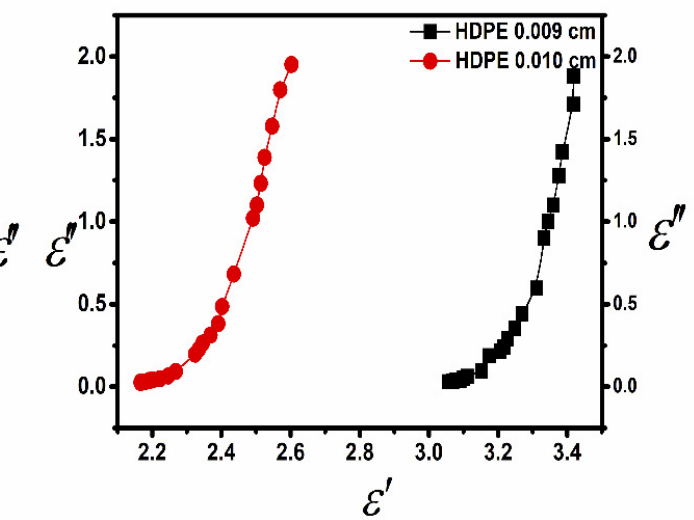

(b)

Figure 7. Cole-Cole plot of (a) LDPE (thickness $0.006 \mathrm{~cm}$ and $0.007 \mathrm{~cm}$ ) and (b) HDPE (thickness $0.009 \mathrm{~cm}$ and $0.010 \mathrm{~cm}$ ) samples.

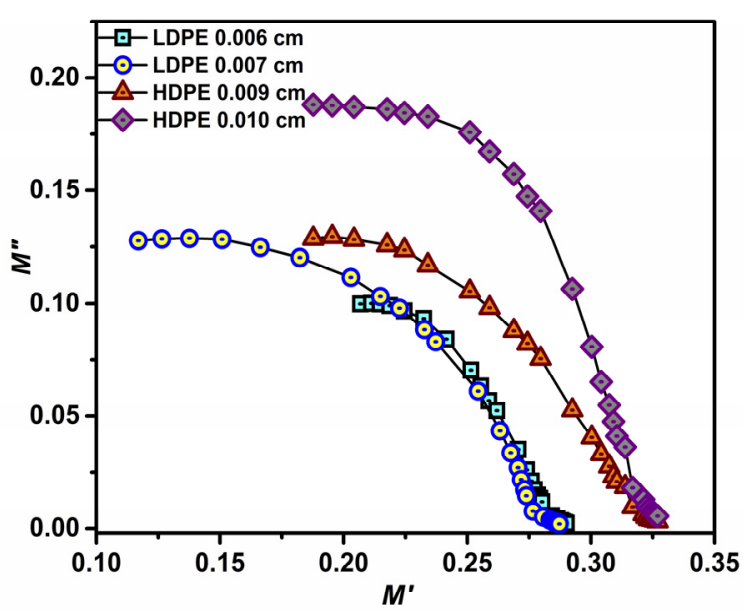

Figure 8. Cole-Cole plot of electrical modulus of LDPE (thickness $0.006 \mathrm{~cm}$ and $0.007 \mathrm{~cm}$ ) and HDPE (thickness $0.009 \mathrm{~cm}$ and $0.010 \mathrm{~cm}$ ) samples.
The Cole-Cole plot of the dielectric data, $\varepsilon^{\prime \prime}$ (loss) vs. $\varepsilon^{\prime}$ (permittivity) is shown in Fig. 7, which is not conventional semicircular type in case of an ideal single relaxation time. The plots are found to be mostly linear with a slight curvature at lowfrequency region, which indicate the presence of wide range of relaxation time. The values of the real part of the electrical modulus $\left(M^{\prime}\right)$ did not equal to zero at low frequencies and it is expected that the electrode polarization may develops in both the sheets. The analysis of real $\left(\varepsilon^{\prime}\right)$ and imaginary $\left(\varepsilon^{\prime \prime}\right)$ parts of dielectric permittivity and that of electrical modulus real $\left(M^{\prime}\right)$ and imaginary $\left(M^{\prime \prime}\right)$ parts (Fig. 8-9) signify poly dispersive nature of relaxation time as shown in Cole-Cole plots. 


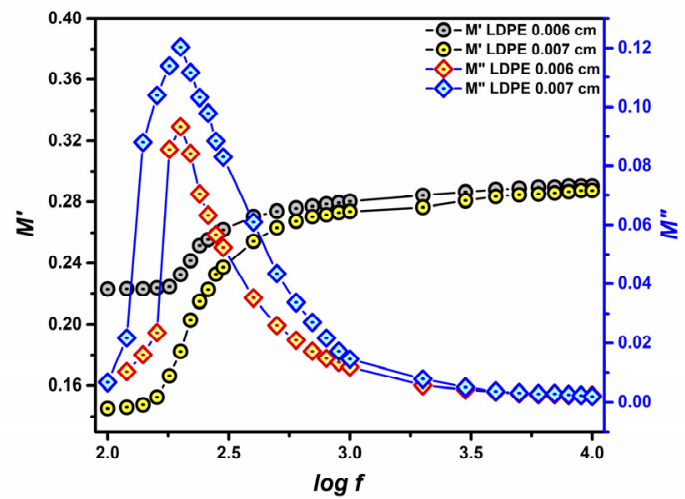

(a)

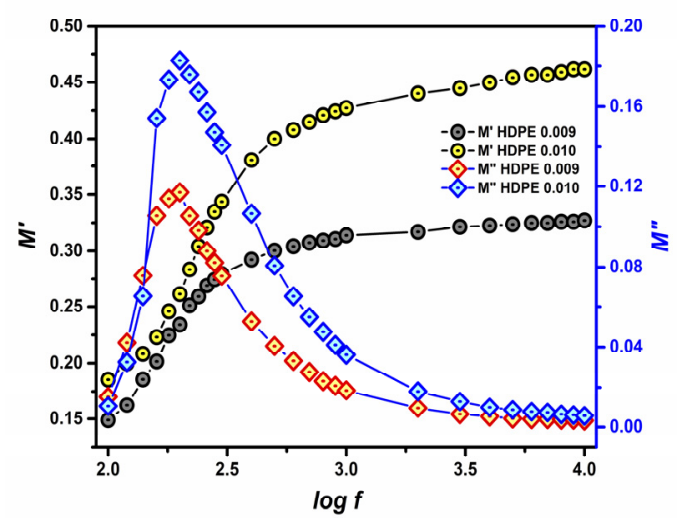

(b)

Figure 9. Variation of electrical modulus with frequency (a) LDPE (thickness $0.006 \mathrm{~cm}$ and $0.007 \mathrm{~cm}$ ) and (b) HDPE (thickness $0.009 \mathrm{~cm}$ and $0.010 \mathrm{~cm}$ ) samples.

The variation of electrical modulus, $M^{\prime}$ and $M^{\prime \prime}$ with frequency (Fig. 9) corroborates the result of $\varepsilon^{\prime}, \varepsilon^{\prime \prime}, \tan \delta$ and $\sigma_{a c}$ of LDPE and HDPE samples.

\section{CONCLUSIONS}

The dielectric constant $\left(\varepsilon^{\prime}\right)$ and dielectric loss factor $\left(\varepsilon^{\prime \prime}\right)$ of LDPE and HDPE polymers have been measured using a dielectric cell. Conductivity $(\sigma)$, dissipation factor $(\tan \delta)$, relaxation time $(\tau)$, electrical modulus $\left(M^{\prime}\right.$ and $\left.M^{\prime \prime}\right)$ for both LDPE and HDPE were studied. The analysis of real and imaginary parts of both dielectric permittivity and electric modulus have been performed, which show the polydispersive nature of relaxation time as confirmed by ColeCole plot, complex permittivity as well as the scaling behavior of the modulus spectra. It is supported by the nature of $\sigma, \tan \delta$ and $\tau$ data in this present study. The frequency dependence of real and imaginary parts of the electrical modulus, $\left(M^{\prime}\right.$ and $\left.M^{\prime \prime}\right)$ for the samples, are depending on the filler content of LDPE and HDPE sheets.

\section{ACKNOWLEDGMENT}

Authors are grateful to the Director, CIPET, Bhubaneswar for providing Laboratory facility to carry out the work.

\section{ORCID IDs}

(D) Sarat K. Dash, https://orcid.org/0000-0001-5075-2129; (DHari S. Mohanty, https://orcid.org/0000-0002-1230-156X

(D) Biswajit Dalai, https://orcid.org/0000-0001-8401-7501

\section{REFERENCES}

[1] S.K. Dash, S. Kant, B. Dalai, M.D. Swain, and B.B. Swain, Ind. J. Phy. 88, 129-135 (2014), https://doi.org/10.1007/s12648013-0395-0.

[2] M.M. Solovan, H.M. Yamrozyk, V.V. Brus, P.D. Maryanchuk, East Eur. J. Phys. 4, 154-159 (2020) https://doi.org/10.26565/2312-4334-2020-4-19.

[3] S. Ghatge, Y. Yang, J.H. Ahn, and H.G. Hur, Appl. Biol. Chem. 63, 27 (2020), https://doi.org/10.1186/s13765-020-00511-3.

[4] R.K. Sarker, P. Chakraborty, P. Paul, A. Chatterjee, and P. Tribedi, Arch. Microbiol. 202, 2117-2125 (2020) https://doi.org/10.1007/s00203-020-01926-8.

[5] D. Manas, M. Manas, A. Mizera, P. Stoklasek, J. Navratil, S. Sehnalek, and P. Drabek, Polymers 10, 1361 (2018), https://doi.org/10.3390/polym10121361.

[6] M. Marin-Genesca et. al. Polymers, 12, 1075 (2020), https://doi.org/10.3390/polym12051075.

[7] D.Q. Tan, J. Appl. Polym. Sci. 137, 1-32 (2020), https://doi.org/10.1002/app.49379.

[8] A.D. Scaccabarozzi, J.I. Basham, L. Yu, P. Westacott, W. Zhang, A. Amassian, I. McCulloch, M. Caironi, D.J. Gundlach, and N. Stingelin, J. Mater. Chem. C, 8, 15406-15415 (2020), https://doi.org/10.1039/D0TC03173A.

[9] A. Usman, M.H. Sutanto, M. Napiah, S.E. Zoorob, S. Abdulrahman, and S.M. Saeed, Ain Shams Eng. J. (2020). https://doi.org/10.1016/j.asej.2020.06.011.

[10] K.S. Samra, R. Singh, and L. Singh, J. Macromol. Sci. Part B Phys. 59, 65-76 (2020), https://doi.org/10.1080/00222348.2019.1687139.

[11] R. Singh, K.S. Samra, R. Kumar, and L. Singh, Radiat. Phys. Chem. 77, 53-57 (2008). https://doi.org/10.1016/j.radphyschem.2007.03.004.

[12] L. Wang, C. Liu, S. Shen, M. Xu, and X. Liu, Adv. Ind. Eng. Polym. Res. 3, 138-148 (2020). https://doi.org/10.1016/j.aiepr.2020.10.001.

[13] D.K. Pradhan, R.N.P. Choudhary, and B.K. Samantaray, Int. J. Electrochem. Sci. 3, 597-608 (2008), http://electrochemsci.org/papers/vol3/3050597.pdf.

[14] C.P. Smyth, Dielectric Behavior and Structure, (McGraw-Hill, New York, 1955).

[15] E. A. Collins et.al, J. Chromatogr. Sci. 13, 12A (1975), https://doi.org/10.1093/chromsci/13.7.12A-b.

[16] S.K. Dash, K.C. Mishra, S.N. Mishra, and B.B. Swain, Indian J. Pure Appl. Phys. 43, 287-290 (2005). 
[17] A.K. Jonscher, J. Mater. Sci. 24, 372-374 (1989), https://doi.org/10.1007/BF00660983.

[18] S. Karmakar, and D. Behera, Appl. Phys. A, 124, 745 (2018), https://doi.org/10.1007/s00339-018-2165-5.

[19] D.K. Ray, A.K. Himanshu, and T.P. Sinha, Indian J. Pure Appl. Phys. 45, 692-699 (2007), http://nopr.niscair.res.in/bitstream/123456789/2639/1/IJPAP\%2045\%288\%29\%20692-699.pdf.

[20] G. Banhegyi, and F.E. Karasz, J. Polym. Sci. Part B Polym. Phys. 24, 209-228 (1986), https://doi.org/10.1002/polb.1986.090240201.

[21] S. Hajra, S. Sahoo, R. Das, and R.N.P. Choudhary, J. Alloys Compd. 750, 507-514 (2018), https://doi.org/10.1016/j.jallcom.2018.04.010.

[22] G.M. Nasr, T.A. Mohamed, and R.M. Ahmed, IOP Conf. Ser. Mater. Sci. Eng. 956, 012002 (2020).

[23] S.A. Saafan, M.K. El-Nimr, and E.H. El-Ghazzawy, J. Appl. Polym. Sci. 99, 3370-3379 (2006), https://doi.org/10.1002/app.23054.

[24] B.A. Shujah-Aldeen, M.Sc. Thesis, University of Sulaimani Iraq, 2007.

[25] A.K. Himanshu, D.K. Ray, and T.P. Sinha, Indian J. Phys. 79, 1049-1052 (2005).

[26] H.S. Mohanty, A. Kumar, B. Sahoo, P.K. Kurliya, and D.K. Pradhan, J. Mater. Sci. Mater. Electron. 29, 6966-6977 (2018), https://doi.org/10.1007/s10854-018-8683-2.

\section{ДОСЛІДЖЕННЯ ЕЛЕКТРИЧНИХ ВЛАСТИВОСТЕЙ ТВЕРДИХ ПОЛІМЕРНИХ ЛИСТІВ (НDРЕ I LDPE) В АУДІОЧАСТОТНОМУ ДІАПАЗОНІ \\ Сарат К. Даш ${ }^{\mathbf{a}}$, Харі С. Моханти ${ }^{\mathbf{b}}$, Бісваджіт Далай \\ ${ }^{a}$ Фізичний факультет, Регіональний інститут освіти (NCERT), Бхубанешвар, Одіша, 751022, Індія \\ ${ }^{b}$ Фізичний факультет, Школа наук, Університет GIET, Гунупур 765022, Одіма, Індія}

У цій роботі були взяті тверді полімерні листи, зразок з поліетилену низької щільності (LDPE) товщиною 0,006 см, 0,007 см, і зразок поліетилену високої щільності (HDPE) товщиною 0,009 см, 0,010 см. Вимірювання електричних властивостей, таких як діелектрична константа $\varepsilon^{\prime}$ та діелектричні втрати $\varepsilon^{\prime \prime}$, для твердих полімерних листів LDPE та HDPE проводилось, використовуючи діелектричний елемент. Було виготовлено діелектричний елемент, який складався 3 двох круглих паралельних пластин із чистої нержавіючої сталі, кожна діаметром 5 см і товщиною 2 мм. Для вимірювання ємності $C$ та коефіцієнта дисипації $D$ в діапазоні звукової частоти (AF), від 100 Гц до 10 кГц, використовували імпедансний міст (GRA 650A). Різні зразки завантажували між двома пластинами елемента, а ємність, а також коефіцієнт дисипації оцінювали за показаннями шкали моста. Вплив зміни частоти на $\varepsilon^{\prime}, \varepsilon^{\prime \prime}$, час релаксації $\tau$, коефіціснт дисипації $\tan \delta$ і провідність змінного струму $\sigma$ також був розглянутий для діапазону звукових частот. Розраховано комплексну діелектричну проникність $\varepsilon^{*}$, пов'язану з вільним диполем, що коливається у змінному полі, та тангенс втрат $\tan \delta$. У цій роботі було досліджено частотно-залежну провідність, діелектричний характер та електричний модуль, дійсну $\left(M^{\prime}\right)$ та уявну $\left(M^{\prime \prime}\right)$ частини LDPE та HDPE. Значення дійсної частини електричного модуля $\left(M^{\prime}\right)$ не дорівнювало нулю на низьких частотах, $\mathrm{i}$ очікується, що поляризація електрода може розвинутися в обох листах. Ці результати виявляють зміцнення зв'язку між локальними диполярними рухами в локалізованому русі ближнього порядку. Аналіз реальної ( $\left.\varepsilon^{\prime}\right)$ та уявної $\left(\varepsilon^{\prime \prime}\right)$ частини діелектричної проникності, а також реальна $\left(M^{\prime}\right)$ та уявна $\left(M^{\prime \prime}\right)$ частини електричного модуля вказують на полідисперсний характер часу релаксації, як це спостерігається на графіках Коул-Коула.

КЛЮЧОВІ СЛОВА: LDPE, HDPE, діелектрична проникність, діелектричні втрати, провідність змінного струму 